\title{
Rootstock Incision Type and the Origin of Bud on the Scion Influence the Success Rate of Budding Propagation of "Rimau Gerga Lebong" Tangerine
}

\author{
Debby Rosya Dhini' ${ }^{1)}$ Hermansyah ${ }^{2)}$, Supanjani ${ }^{2)}$ \\ ${ }^{1)}$ Graduate Student of Agroecotechnology Study Program, Faculty of Agriculture, The University of Bengkulu \\ Jl.WR Supratman, Kandang Limun, Bengkulu 38371A- Indonesia \\ ${ }^{2)}$ Department of Crop Production, Faculty of Agriculture, The University of Bengkulu, Bengkulu- Indonesia \\ J1.WR Supratman, Kandang Limun, Bengkulu 38371A- Indonesia
}

\author{
ARTICLE INFO \\ Keywords: \\ Rimau Gerga Lebong \\ tengerine \\ Budding \\ incision model \\ scion

\section{Article history:} \\ Received: March 24, 2018 \\ Accepted: Aug 26, 2018 \\ *Corresponding author: \\ E-mail: 13debbyros@gmail.com
}

\begin{abstract}
The development of citrus crops is directed to produce tangerine plants that lead to substitute imported fruits by the development of budding seedlings technique using local varieties citrus. This research was conducted in November 2016 until March 2017 in citrus nursery of Horticultural Seed Center of Pematang Donok Village, Kabawetan Sub-district, Kepahiang Regency, Bengkulu Province. The research was arranged in a Completely Random Design with combination of two treatments, the first treatment was the origin of bud on the scion plant, they were E1 (upper part of the shoot scion), E2 (middle part of the shoot scion), E3 (basal of the shoot scion). The second treatment was cut type on the rootstock, they were J1 (H type), J2 (Forkert slice), J3 ( $\mathrm{T}$ wedge). The treatment was repeated three times, so there were 27 experimental units. Each experimental unit consisted of 10 liners, so there were 270 liners of the experiment. The result of this research showed that incision types of $\mathrm{H}$ model and Forkert model, as well as the bud originated from the middle and the basal part of shoot scion were good to support the success rate of budding propagation of Rimau Gerga Lebong (RGL) tangerine.
\end{abstract}

\section{INTRODUCTION}

Orange is one of horticulture commodities that developed in Indonesia (Dirjen Hortikultura, 2012). Oranges are widely cultivated because the fruit is popular with people (Agricultural Research and Development Agency, 2007). According to Lelly (2004) orange juice contains $50 \mathrm{mg} / 100 \mathrm{ml}$ source of vitamin $\mathrm{C}$, vitamin $\mathrm{A}$ and protein.

Food independence program needs to be supported by the availability of non-staple food crops such as oranges (Widodo et al., 2015). The availability of an inadequate national citrus causes the import of oranges to increase by $11 \%$ annually (Hanif and Zamzani, 2012). This makes oranges as the national superior fruit of government program (Irianto, 2009). Government programs in the development of citrus crops are directed to produce tangerines in order to become import substitutes (Kuntarsih, 2008). According to Setyobudi (2010) citrus development invloves social, economic and environmental aspects.
The alternative to reduce the number of tangerine imports is the development of local varieties of tangerines, one of which is Rimau Gerga Lebong (RGL) which is a local plant of Bengkulu (Suwantoro, 2010). RGL has a specification such as the large size and stiff leaves, thick fruit skin, with sweet and sour fruit flavored (BPSB, 2012).

Increased fruit production should be supported by the availability of plant materials (Prasetyo, 2009). Successful development is determined by the availability of high quality seedlings at the right time and in quantities as needed. The use of unsuitable seeds and varieties will lead to difficulties in subsequent crop management (Hatta et al., 1992). Therefore, research, development and management of nurseries need to be improved to meet the demand for seedlings for consumers (Samekto et al., 1995). However, generative conventional breeding will take a long time and the characteristics of the new plants will be different from that of the parent plant (Sumarsono, 2002). Therefore, an alternative that can be attempted is the development of citrus fruits

ISSN: 1410-3354 / e-ISSN:2615-7136

Cited this as: Dhini, D.R., Hermansyah, Supanjani. 2018. Rootstock incision type and the origin of bud on the scion influence the success rate of budding propagation of "Rimau Gerga Lebong" tangerine . Akta Agrosia 21(2):41-46. 
with the use of good quality seedlings that are vegetative propagated (Pracaya, 1992).

Budding is one of the vegetative propagation techniques by sticking the eye bud from a plant to other plants that is compatible each other (Simanjuntak, 2010). The advantages of using grafting include strong rootstocks, accelerated reproductive periods, gaining favorable growth conditions, cheaper costs, requiring less mature planting material and can produce many seedlings (Hartmann et al. , 1990).

Development of local tangerine with good quality seedlings would require the technique of grafting and the right tangerine varieties as well. One of the development efforts is by using scion of Rimau Gerga Lebong (RGL) oranges and rootstock Japanese Citroen (JC). Generally, farmers use all eyes scion on branch entrants are available for making budding. Though each eye scion have different age according to its location in shoot. Budding has several methods in opening windows, including the model slices of $\mathrm{H}$, Forkert and $\mathrm{T}$ window model. The objective of this study was to obtain the appropriate grafting technique from the combination of eye scion (buds) sources and cut model which leads to the best rate of budding.

\section{MATERIALS AND METHODS}

This research was conducted in November 2016 until March 2017 in citrus nursery of Horticultural Seed Center of Pematang Donok Village, Kabawetan, Kepahiang Regency, Bengkulu Province. The elevation of the area is $650 \mathrm{~m}$ above sea level .

This research was arranged with Factorial Random Design (RAL) with two factors, the first factor is the position of scion denoted by "E", consisting of E1 (the location of the branch head scion), E2 (the center branch), E3 ( the position of the branch base scion). The second factor is the slice of window model symbolized by "J", consisting of $\mathrm{J} 1$ (slice H), J2 (Forkert slice), J3 (T wedge) of 9 treatment combinations, each treatment repeated three times, so there ware 27 experimental units. Each experimental unit consisted of 10 seeds, so there were 270 grafts.

Land cleared from weeds and plant remnants, then 27 ditches was dug with length size $200 \mathrm{~cm}$ x 15 $\mathrm{cm}$ wide. The distance between ditches was $50 \mathrm{~cm}$. Seedlings were planted on beds with the distance between seedling was $5 \mathrm{~cm}$. Shading was built with the height 2 meters from the ground to prevent seedlings from direct sun.

The rootstock used was Citroen Japanase orange (JC) variety of citrus seedlings that were kept at the Horticulture Seed Center of Kepahiang, those of which were grown in polybags and ready for buddings. Selection of 8 months old rootstock was done by choosing the size of the rootstock diameter of $0.8 \mathrm{~cm}$ to $1 \mathrm{~cm}$. The selected seeds were placed under shade and arranged according to experimental design arrangement. All shoots that grow on the rootstock were cut $30 \mathrm{~cm}$ from the base of the stem and labeled according to treatment. The branches for the scion wass derived from the parent tree of Rimau Gerga Lebong (RGL). The parent trees used were the certified trees, free from pest and disease, and have already known bearing good fruit. The third branch of the parent tree was cut, the buds along the branch were grouped into three parts according to the treatments i.e. the top, the middle and the basal parts.

The budding was performed by cutting the rootstock stem according to the treatments, i.e. $\mathrm{H}$ model, the Forkert model, T wedge model. Green buds of RGL orange was slashed carefully from the top down $2 \mathrm{~cm}$ long, and then it was inserted in the slit window, wrapped with plastic from the bottom up. The buds were unwrapped 3 weeks afterward, the main stem of the rootstocks were cut at the distance $10 \mathrm{~cm}$ from the budding joint followed by cutting the main stem at the angle of $45^{\circ}$ to $60^{\circ}$ when the new shoots of successful budding were grown up.

Plant maintenance included the disposal of shoots that grow on the rootstock seedlings. Watering was done every morning using a manual hose until the soil becomes moist. Fertilization was done 11 weeks after grafting with cowdung 10 gram / polybag. Weed control is done manually sickle. Pests were controlled chemically using Imidatide $1 \mathrm{ml} / \mathrm{L}$ when the palnts were 7 and 9 weeks old. Carbofuran were stocked around the fence to prevent pests from entering the area.

Observations of plant variables included: Percentage of success budding, Percentage of dead budding, Percentage of dorman budding, Percentage of shooted budding, Shoot length $(\mathrm{cm})$, Number of leaves, and Time to shoot (weeks after budding). Air temperature and humidity were recorded as supporting data. The observed data is transformed using $\sqrt{y+0.5}$ then analyzed using Anava with $\mathrm{F}$ test using Costat software at $5 \%$ and $1 \%$ level. The Least Sinificant Difference analysis at 5\% level was applied on data which are different significantly.

\section{RESULTS AND DISCUSSION}

The study was conducted in the rainy season with an average air temperature of $24.2^{\circ}$ Celsius and average air humidity of $65.1 \%$. Of all plants used inthis study, 181 plants (67\%) kept live and 89 plants (33\%) were found dead.

During the study there were several RGL citrus seeds that were inoculated showing symptoms of pest attacks such as caterpillars in the form of leaf slippers and chewing leaves. This causes the condition of some young leaves of grafting seeds to experience damage such as hollow leaves and leaves marks of elongated white lines elongated on the leaf surface. This pest attack can be chemically controlled that is using insecticide with active ingredient Imikloprid $1 \mathrm{ml} / \mathrm{L}$ and Carbofuran.

The results of variables observation of the effect of window slice model and the location of the scion to the success rate of Rimau Gerga Lebong is presented in Table 1. The observation data has the value of diversity coefficient ranging from $13.37 \%$ to $52.24 \%$. The lowest value is the percentage of life 
Table 1. Analysis of variance effect of incision type and the origin of scion bud to the success rate of grafting of Rimau Gerga Lebong Tangerine

\begin{tabular}{lcccc}
\hline \multirow{2}{*}{ Variables } & \multicolumn{3}{c}{ F -Values } & CV \\
\cline { 2 - 4 } & $\mathrm{J}$ & $\mathrm{E}$ & $\mathrm{J} \times \mathrm{E}$ & $(\%)$ \\
\hline Percent life & $9.82^{* *}$ & $0.53 \mathrm{~ns}$ & $1.61 \mathrm{~ns}$ & 13.37 \\
Percent death & $7.76^{* *}$ & $1.66 \mathrm{~ns}$ & $1.44 \mathrm{~ns}$ & 30.75 \\
Percent dorman & $0.47 \mathrm{~ns}$ & $1.20 \mathrm{~ns}$ & $0.77 \mathrm{~ns}$ & 52.24 \\
Percent sprout & $17.48^{* *}$ & $3.68^{*}$ & $0.60 \mathrm{~ns}$ & 15.39 \\
Growth shoot & $3.32 \mathrm{~ns}$ & $0.88 \mathrm{~ns}$ & $0.44 \mathrm{~ns}$ & 15.51 \\
Shoot length & $10.08^{* *}$ & $2.21 \mathrm{~ns}$ & $0.46 \mathrm{~ns}$ & 25.15 \\
Numb.leaves & $9.53^{* *}$ & $1.92 \mathrm{~ns}$ & $0.30 \mathrm{~ns}$ & 23.05 \\
\hline
\end{tabular}

Note : $*$ significant effect on u ji $\mathrm{F}$ level of $5 \%, * *=$ effect on real F-test level of $1 \%$, ns $=$ not significant, $\mathrm{J}=$ models wedge grafting window, $\mathrm{E}=$ layout grafting buds, $\mathrm{JxE}=$ interaction,

budding, while the highest value is the variable percentage of dormant budding. The oculation death due to treatment effect resulted in a high range of coefficient variability values to the experiment.

The result of variance showed that the slice model of the grafting window had a significant effect on the percentage of , the percentage of death, the percentage of sprout, the shoot length and the number of leaves, had no significant effect on the dormant percentage and the shoot growing time. The location of eye scion had significant effect on the $5 \%$ level to the sprout percentage and had no significant effect on the percentage of live, the percentage of death, the percentage of dormant, the growth time of the bud, the length of the shoot and the number of leaves. The influence of the window slice model and the location of the scion eye did not interact significantly with all observation variables.

\section{Effect of RGL Orange Grass Oxide Modeling Model}

The LSD test of live percentage percentage, dead percentage, percentage of sprout, shoot length and number of leaves on window slice model presented on Table 2 .

\section{Percentage of Life Budding}

Live grafting was seen 3 weeks from the implementation of grafting by opening the plastic wrapping grafts and observing the sciones. If the scion are still green, fresh and not broken then the grafting can be categorized as success and have a chance to grow. The grafting successfully lived on citrus seedlings RGL had the best live percentage on the slice model of window $\mathrm{H}$ ie $80 \%$ and Forkert window slice model that is $73.3 \%$, both not significantly different but significantly different with the $\mathrm{T}$ shell window model that is $47.8 \%$.
In the implementation of the grafting, the Forkert model of Forkert grafting window is the easiest model to carry out because it is carried out in two stages: stripping of bark by cutting transverse bark and then drawn down $2 \mathrm{~cm}$. The slice model of the $\mathrm{H}$ oculation window is an enhanced Forkert model. Implementation of opening the window has a slight change so that the shape of the slice is like the letter $\mathrm{H}$. The slice model of window grafting $\mathrm{H}$ has three stages of execution that exfoliates the bark by cutting the stem bark to form the letter $\mathrm{H}$, then stem bark peeling is done by pulling the bark of the stem up along $1 \mathrm{~cm}$ and down $1 \mathrm{~cm}$ long as well.

The T grafting window model is a sliced window model that has three stages of cutting the stem shell to form the letter $\mathrm{T}$, then exfoliation is done by pulling the bark from the intersection point to the right and left. Low percentage of life in the $\mathrm{T}$ shaped window model due to the cambium can be damaged scratched by the knife when opening the window grafting, especially in the middle of which will be attached scion and skin of citrus seedlings are relatively small chance to cause skin rod tear when the window is opened. Implementation of the grafting using the $T$ shirt slice model needs to be very careful and takes a longer time from the slice model of the $\mathrm{H}$ window and the Forkert window slice model. According to research by Budiman (2012), the grafting with the $\mathrm{T}$ model has a lower success percentage of 30\% than the square model oculation which reaches $63 \%$ success percentage. This suggests that the difficulty of execution can lead to low levels of grafting success.

\section{Percentage Of Death Budding}

The result of observation of the effect of slice model of the grafting window on the percentage of dead orange RGL shows the percentage of die on the slice model of the $\mathrm{H}$ apulation window that is $20 \%$ and the Forkert window slice model is $26.7 \%$, both of which are not significantly different but significantly different from the $\mathrm{T}$ filtration window model that is $52.2 \%$.

The grafting performed on the slice model of the $\mathrm{H}$ window and the Forkert window slice model resulted in more live grafting than dead. Forkert grafting window slices model in one working hour can reach the amount of grafting of 150 citrus seedlings. The number indicates the Forkert model was chosen because its use is not that time consuming and has few implementation stages. While the implementation time of model $\mathrm{H}$ is much longer than the Forkert model that is in one hour of work pengokulasian can reach the amount of grafting 120 citrus seedlings. The slices of the $\mathrm{T}$ window produces

Table 2. Test of LSD of incision type of budding to the success rate of RGL tangerine

\begin{tabular}{cccccc}
\hline Slice window model & $\begin{array}{c}\text { Percent life } \\
(\%)\end{array}$ & $\begin{array}{c}\text { Percent deat } \\
(\%)\end{array}$ & $\begin{array}{c}\text { Percent } \\
\text { sprout } \\
(\%)\end{array}$ & $\begin{array}{c}\text { Shoot } \\
\text { length } \\
(\mathrm{cm})\end{array}$ & $\begin{array}{c}\text { Numb of } \\
\text { leave }\end{array}$ \\
\hline $\mathrm{H}$ & $80.0 \mathrm{a}$ & $20.0 \mathrm{~b}$ & $67.8 \mathrm{a}$ & $9.2 \mathrm{a}$ & $5.7 \mathrm{a}$ \\
$\mathrm{F}$ & $73.3 \mathrm{a}$ & $26.7 \mathrm{~b}$ & $62.2 \mathrm{a}$ & $6.7 \mathrm{a}$ & $4.6 \mathrm{a}$ \\
$\mathrm{T}$ & $47.8 \mathrm{~b}$ & $52.2 \mathrm{a}$ & $30.0 \mathrm{~b}$ & $2.9 \mathrm{~b}$ & $2.0 \mathrm{~b}$ \\
\hline
\end{tabular}

Note: The number in the column same followed by the same letter, no different based on $5 \%$ BNT 
the grafting of seeds that are more dead than life.

The $\mathrm{T}$ window grafting model is a slice of window model that has three stages. Its execution takes a longer time and causes the cambium to be attached to the eye scion more susceptible to contamination by microorganisms. This causes the grafting with the $\mathrm{T}$ shell window model to fail greater than the implementation of the grafting model of the Forkert grafting window with two stages of the slice model implementation of the $\mathrm{H}$ oculation window with three stages of implementation. According to McMahon et al. (2007), the connection between the rootstock and the shoot of the upper stem begins the formation of callus tissue in the cambium area on the stem side attached, when the lining of the callus is not formed, the sticking surface of the stem can not be fused so the bud eye will brown and dry.

\section{Percentage Bud}

The observation result on percentage variables of sprout shows the slice model of window $\mathrm{H}$ i.e. $67.8 \%$ and the Forkert window slice model is $62.2 \%$, both have the percentage of sprout is not significantly different but is significantly different with the $\mathrm{T}$ shell window model that is $30 \%$. The presence of spinning grafting seeds in accordance with the statement Acquaah (2004) that grafting can be said to succeed after the top stem can actively grow and develop well. The condition is possible when the nutrient exchange exchanges from the rootstock to the top stem, with organic compounds result photosynthesis from the top stem to the rootstock. According to Noer and yusran (2011) the growth of budscan occur after the link between the eyes scion and rootstock. Connection occurs due to the compatibility that is close enough so that the next growth takes place. Each tree has different cleavage times. This allows different cleavage times to result in different budding times of each plant being inoculated (Wudianto, 2002).

\section{Shoot Length}

From observation of long bud growth for 14 weeks, each plant has significant shoot growth time within 2 weeks from after shoot.Then shoots staknasi with long feature buds that do not grow or not grow. However, there is a development in the buds is the increase in chlorophyll so that during shoots stagnant stronger and grows greenish to dark green.

The result of observation showed that the length of shoots between the incision model $\mathrm{H}(9.2 \mathrm{~cm})$ and the Forkert model $(6.7 \mathrm{~cm})$ is not significant, but both of them was significantly different with the $\mathrm{T}$ wedge model $(2.9 \mathrm{~cm})$. Plant growth begins with the accumulation of carbohydrates in plants (Hidayat et al ., 2005). According Nurhasanah (2003) the growth of bud begins by hormonal process followed by supply of nutrients to the growing point. Widodo (2015) states that plants continue to grow every time resulting in cell division and enlargement.

\section{Number of Leaf}

The result of observation showed that the number of leaves on the slice model of the $\mathrm{H}$ window is 6 strands and the Forkert window slice model is 5 strands, both of which have the number of leaves are not significantly different but significantly different with the T shank slice model which is 2 strands. The growth of shoots is followed by leaf growth on shoots, so the number of leaves on the shoots follows more bud growth (Yusran and Abdul, 2011). At the time of buds stagnated then the leaves will also experience it. Leaves stagnate when all the bud leaves that appear at the beginning of the bud is perfectly open. According to Paramita (2002) the increase of leaf affect the surface area of plant leaves, the more leaves are formed then the plants will produce photosintate that many also to support the growth of buds.

\section{Percentage of Dormant Bud and Time to Shoots Greow}

The observed mean value of dormant percentage and shoot growing time on various slices of window model is presented in Table 3. In Table 3 it is seen that the treatments of the three models of window slices ie the slice model of window $\mathrm{H}$, the Forkert window slice model and the $\mathrm{T}$ wedge window model have no statistically significant effect on the dormant percentage variable and the shoot growing time. The average dormant percentage in the treatment of slice window model is $13.7 \%$ with a value ranging from $11.1 \%$ to $17.8 \%$. The eyes of dorman scion are shown on. The average growing time of shoots in the window slice treatment model was 6.9 weeks with values ranging from 5.8 weeks to 8.6 weeks.

Eye scion dorman is the eye scion in a state of rest, not broken buds and will grow when getting nutrition from the result of photosynthesis of parent plants (Widodo et al ., 2015). According to Wudianto (2002), each tree has different cleavage time. This allows different cleavage time to result in different shoots growing time from each plant being inoculated.

\section{The Influence of scion Eyes on RGL Citrus Supplements, Percentage Sprouted}

The influence of the position of the scion eye on the sprout percentage is presented in Figure 6. scion is the top trunk candidate which is the most important component besides the rootstock candidate in the process of making the seeds. The availability of scion can be a limiting factor that impedes the process.

The result showed that the percentage of sprout grafting of the eye scion of the base part of $57.8 \%$

Table 3. Average percentage of dormant and time to grow shoots pad a variety of models sliced window

\begin{tabular}{ccc}
\hline \multirow{2}{*}{$\begin{array}{c}\text { Window } \\
\text { slice model }\end{array}$} & \multicolumn{2}{c}{ Variable observations } \\
\cline { 2 - 3 } & $\begin{array}{c}\text { Percent } \\
\text { death (\%) }\end{array}$ & $\begin{array}{c}\text { Week to shoot } \\
\text { growth (weeks) }\end{array}$ \\
\hline $\mathrm{H}$ & 12.2 & 5.8 \\
$\mathrm{~F}$ & 11.1 & 6.3 \\
$\mathrm{~T}$ & 17.8 & 8.6 \\
\hline Average & 13.7 & 6.9 \\
\hline
\end{tabular}


and the oculation of the middle edge of the eye is $60 \%$, both of which are not significantly different but the difference is true with the grafting of the tip of the shoot scion of $42.2 \%$ (Table 4 ). The location of the tip of the bud scion is the eye scion that cambium still in the stage of growing and developing so that

Table 4. Further test of BNT position of scion to the success of grafting of RGL Orange

\begin{tabular}{lc}
\hline The Branch of scion & Percentage Sprouted \\
\hline Shoots & $42.2 \mathrm{~b}$ \\
Central & $60.0 \mathrm{a}$ \\
The base & $57.8 \mathrm{a}$ \\
\hline
\end{tabular}

Ket: The numbers in the same column followed by the same letter, do not differ based on the 5\% LSD.

the cambium has not formed perfectly. The location of the middle and base of the scion is the older scion of the eye which allows the cambium to have formed more perfectly and causes scion to interlock with the rootstock more easily. This leads to the scion of the top shoot for linking with a small rootstock.

This is in accordance with research Sumarsono et al. (2002) the success of durian grafting using old scion reach $77.7 \%$ higher than the old scion that is $62.7 \%$ and young scion is $60 \%$. Eyes taken $10-20 \mathrm{~cm}$ from the tip of the branch resulted in a greater percentage of the grafting $(70 \%)$ than the $10 \mathrm{~cm}$ from the tip $(60 \%)$ and above $20 \mathrm{~cm}$ from the tip of the branch $(62 \%)$.

\section{Percentage of Life Bud, Death Bud, and Dormant Bud, Time of Growing Shoot, Lenght of Bud, and Number of Leaves}

The observation of the effect of the location of the buds on the percentage of live, dead percentage, the percentage of dormant, time to sprout, shoot length and number of leaves Orange RGL presented in Table 5 .

Table 5 shows that the third treatment of the scion eye is mama scion shoot, middle scion eye and base eye eye have no statistically significant effect on the percentage of life variable, percentage of death, dormant percentage, bud growth time, shoot length and number of leaves. This is thought to be due to the treatment of scion green eyes entirely.

Table 5. Mean value of live percentage, percentage of death, percentage of dormant, growth of buds, bud length and number of leaves at various locations of entres

\begin{tabular}{lcccccc}
\hline LME & $\begin{array}{l}\text { PH } \\
(\%)\end{array}$ & $\begin{array}{c}\text { PM } \\
(\%)\end{array}$ & $\begin{array}{c}\text { PD } \\
(\%)\end{array}$ & $\begin{array}{c}\text { WTT } \\
(\text { week })\end{array}$ & $\begin{array}{c}\text { PT } \\
(\mathrm{cm})\end{array}$ & JD \\
\hline Shoots & 61.1 & 38.9 & 18.9 & 7.5 & 4.5 & 3.0 \\
Central & 70.0 & 30.0 & 10.0 & 6.2 & 7.7 & 4.9 \\
The base & 70.0 & 30.0 & 12.2 & 7.0 & 6.6 & 4.4 \\
\hline Average & 67.0 & 33.0 & 13.7 & 6.9 & 6.3 & 4.1 \\
\hline
\end{tabular}

Note: $\mathrm{LME}=$ Entres eye location $\mathrm{PH}=$ Percentage of Life, $\mathrm{PM}=$ Percentage of Death, $\mathrm{PD}=$ Percentage Dorman, WTT $=$ Time of Tunas, PT $=$ Long Shoots, JD = Number of Leaves
The average percentage of live treatment of the location of scion is $67 \%$ with a value ranging from $61 \%$ to $70 \%$. The average percentage of die treatment of eye position is $33 \%$ with values ranging from $30 \%$ to $39 \%$. The average percentage of dormant treatment of eye scion is $14 \%$ with values ranging from $10 \%$ to $19 \%$. The average growth time of buds treatment is 7 weeks with grades ranging from 6 weeks to 7 weeks. The average length of shoots treatment of eye scion is $6.3 \mathrm{~cm}$ with values ranging from $4.5 \mathrm{~cm}$ to $7.7 \mathrm{~cm}$. The average number of leaves treated the eye scion position is 4 strands with values ranging from 3 strands to 5 leaves.

\section{CONCLUSION}

The model of slice of the grafting window and the location of the scion did not interact significantly with the success of the grafting of Rimau Gerga Lebong (RGL). The sliced window model with a good grafting success rate of Rimau Gerga Lebong (RGL) plant was obtained in $\mathrm{H}$ and Forkert model, while which is poorly obtained on the T model.

The location of eye scion with the good grafting success rate of Gerau Betga Gerber Lebong (RGL) plant is obtained at the center of the branch and the base of the branch from the third branch of the mother tree, while the bad is obtained at the top of the branch.

\section{REFERENCES}

Acquaah, G. 2004. Horticulture Principles and Practice.Ed ke-3.Pearson Prentice Hall. New Jersey.

Badan Penelitian dan Pengembangan Pertanian 2007, Prospek dan Arah Pengembangan Agribisnis Jeruk, Departemen Pertanian.

Balai Pengawasan dan Sertifikasi Benih Propinsi Bengkulu. 2012. Deskripsi Jeruk RGL.

Dinas Pertanian Propinsi Bengkulu. Bengkulu.

Budiman, V. P. 2012. Pengaruh Letak Mata Tunas Dan Model Okulasi Terhadap Tingkat Keberhasilan Okulasi Beberapa Aksesi Jarak Pagar (Jatropha curcas). Skripsi.Fakultas metematika dan ilmu pengetahuan alam.IPB. Bogor.

Dirjen Hortikultura. 2012. LAKIP Direktorat Jenderal Hortikultura Tahun 2012. Kementerian

Hanif, Z dan L, Zamzami. 2012. Trend Jeruk Impor dan Posisi Indonesia sebagai Produsen Jeruk Dunia. Biology and Technology (43) : 271-279.

Hartmann, H. T., D.E. Kester danJr. F.T. Davies. 1990. Plant Propagation, Principles And Practicefifth Edition. Prentice Hall, Inc. Englewood. New Jersey. $578 \mathrm{hlm}$.

Hatta, M. L., Hutagalung., Juhasdi dan Modding. 1992. Perngaruh Model Okulasi Terhadap Keberhasilan Penempelan pada Sirsak. Jurnal Hortikultura. 2 (2): 55-58.

Hidayat, R. S., Poerwanto ., R. Latifah., Darusman dan Purwoko. 2005. Kajian Periode Dormansi dan Ritme Pertumbuhan Tunas dan Akar 
Tanaman Manggis (Garcinia mangostana L.).Institut Pertanian Bogor. Bogor. Bul Agron. 33 (2): 16 - 22.

Irianto, S. G. 2009. Peranan iptek dan litbang dalam memperkuat daya saing buah-buahan nusantara.Prosiding Seminar Nasional Buah Nusantara. 5 - 9 hlm.

Kuntarsih, S. 2008. Pengelolaan Rantai pasok agribisnis jeruk (kasus jeruk Siam Pontianak, Kabupaten Sambas).Prosiding Seminar Nasional Jeruk 2007.60-74 hlm.

Lelly, S. 2004. Teknik Perbanyakan Vegetatif Tanaman Jeruk Manis (Citrus sinensis (L) Osbeck). Skripsi. Departemen Budidaya Pertanian. Fakultas Pertanian. Institut Pertanian Bogor. Bogor.

McMahon, M. J., M. K. Anton dan E. R. Vincent. 2007. Hartmann's Plant Science Growth, Development, and Utilization of Cultivated Plants, Ed ke-4. Pearson Prentice Hall. New Jersey.

Noer, A. H dan Yusran. 2011. Tingkat Keberhasilan Okulasi Varietas Keprok So E dan Keprok Tejakula Pada Berbagai Dosis Pupuk Organik. Biocelebes. Fakultas Pertanian Universitas Tadulako. Tadulako. 5 (1) : 22-30

Nurhasanah, F. 2003. Keberhasilan Okulasi Jeruk Manis 'Ansui' (Citrus Sinensis (L.) Osbeck) Pada Batang Bawah Jeruk Rough Lemon (Citrus Jambhiri Lush) Yang Berpengaruh Umur Dan Cara Penanamannya.Skripsi.Institut Pertanian Bogor. Bogor.

Paramita, D. 2002. Pengaruh Jumlah Batang Bawah dan Tingkat Kedewasaan scion terhadap Pertumbuhan Bibit Tanaman Manggis ( Garcinia mangostana L.) di Lapangan. Skripsi.Institut Pertanian Bogor. Bogor.

Pracaya. 1992. Jeruk Manis: Varietas, Budidaya dan Pascapanen. Penebar Swadaya. Depok.158 hlm.
Prasetyo, H. 2009. Kajian Umur Batang Bawah Pada Dua Macam Sistem Perbanyakan Tanaman Jeruk. Agritek. 17(5) : 908-917

Samekto, H., A. Supriantono dan D. Kristianto.1995. Pengaruh Umur dan Bagian Semaian Terhadap Pertumbuhan Stek Satu Ruas Batang Bawah Jeruk Japanese Citroen.Jurnal Hortikultura. 5 (1): 25-29.

Setiono dan A. Supriyanto. 2004. Keunggulan teknik perbanyakan okulasi irisan pada tanaman jeruk. Loka Penelitian Tanaman Jeruk dan Hortikultura Subtropik-Tlekung. Malang.

Setyobudi, L. 2010. Pengelolaan Tanaman Jeruk Siam (Citrus suhulensis Tan.) Secara Berkelanjutan. Jumal Agroekoteknologi. 1(1):16-20

Simanjuntak, F. 2010. Pembiakan Vegetatif. Penebar Swadaya. Jakarta.

Soelarso, B. 1996.Budidaya Jeruk Bebas Penyakit. Kanisius.Yogjakarta.

Sumarsono, L., A. Sjaefuddin., D. Dimyati dan Abdurahman. 2002. Teknik Okulasi Bibit Durian pada Stadia scion dan Model Mata Tempel yang Berpengaruh. Buletin Teknik Pertanian. 7 (1) : 1-3

Suwantoro, B. 2010.Mengenal Jeruk Rimau Gerga Lebong Lebih Dekat. Balai Benih Hortikultura Rimbo Pengadang. Dinas Pertanian dan Ketahanan Pangan Kabupaten Lebong.Bengkulu.

Widodo, W., S. Z. Arifin dan M. R. Asmuri.2015. Keberhasilan Tiga Kultivar Kelengkeng Pada ruas Batang yang Berlainan. Seminar Nasional. Universitas PGRI Yogyakarta.Yogyakarta.

Wudianto, R. 2002. Cara Membuat Setek, Cangkok dan Okulasi. Penebar Swadaya. Jakarta.

Yusran dan H. N. Abdul. 2011. Keberhasilan Okulasi Varietas Jeruk Manis Pada Berbagai Perbandingan Pupuk Kandang. Media Litbang.Sulawesi Tengah. 4 (2) : 97-104 